\title{
Studying influence of gene-modified soya of line MON 89788 on an organism of laboratory animals
}

\author{
Mandygra M. ${ }^{1}$, Doletskyi S. ${ }^{2}$, Kutsan $0 .{ }^{3}$, Shev-tsova G. ${ }^{4}$, Romanko M. ${ }^{5}$, Orobchenko $0 .{ }^{6}$, Herilovych I. ${ }^{7}$ \\ 1, ${ }^{2}$ National academy of agrarian sciences of Ukraine, Mykhailo Omelianovych-Pavlenko Str., 9, Kyiv, 01010, \\ Ukraine, ${ }^{3-7}$ NSC «Institute of experimental and clinical veterinary medicine», Pushkin Str., 83, Kharkiv, \\ 61023, Ukraine; e-mail: 1, 2vet_uaan@meta.ua, ${ }^{3}$ okutsan@ukr.net, ${ }^{4-7}$ toxy-lab@ukr.net
}

The purpose. To study influence of trans-gene soya of line MON 89788 on an organism of laboratory animals. Methods. Toxic-hygienic researches were spent on the basis of department of toxicology, safety and quality of agricultural production of NSC «IEKVM» in view of main principles of bioethics. Experiment in vivo has been put on males of white mice (90 days). Before the beginning of the experiment animals were divided by the principle of analogues into 3 groups (20 animals in each group) and during 10 days maintained in the leveling period. In the further mice of control group received basic diet (BD) - grain mix without soya. Mice of the I-st group received $\mathrm{BD}$, in which $30 \%$ of weight of grain was replaced with crushed and thermally processed $\left(120^{\circ} \mathrm{C}, 30 \mathrm{~min}\right)$ soya of average ripeness without genic modification; mice in the II-nd group - received $\mathrm{BD}$, in which $30 \%$ of weight of components was replaced with crushed and thermally processed $\left(120^{\circ} \mathrm{C}, 30 \mathrm{~min}\right)$ soya of line MON 89788. During experiment with mice they carried out clinical supervision (considered appetite, consumption of water, reaction on external irritation, behaviour, etc.) . On the 21-st, 45-th and 90-th day from the beginning of experiment they carried out mice euthanizing by decapitation with the use of chloroformic narcosis ( 5 animals from each group). They also selected blood samples for carrying out the further biochemical researches and paid attention to presence of pathological-and-anatomic changes. Results. Longterm receipt (during 90 days), unlike short-term (during 21, 45 days), in an organism of laboratory animals of soya of line MON 89788 led to negative results. Pathological-and-anatomic changes in liver and gastroenteric path were revealed. By biochemical markers (increase of activity alaninaminotranspherase in all periods of research, increase of concentration of gama-globulins, for 21 day of experiment moderate growth of betaglobulins $(P \leq 0,05)$, authentic increase of content of general protein for 90-th day) was fixed heavier infringement of functional state of liver at animals who received modified soya, rather than traditional one. Conclusions. It is expedient to continue researches of transgenic soya with the use of other kinds of laboratory and agricultural animals.

Key words: GM-soya of line MON 89788, white mice, pathological-and-anatomic changes, functional state of liver, blood plasma.

https://doi.org/10.31073/agrovisnyk201809-05

The volumes of transgenic crops have been increasing from year to year, despite the public concern caused by insufficient study of the impact of genetically modified organisms (GMOs) on the human and animal health, and an environment. Furthermore, thanks to the development of genetic engineering technology in the world, new lines of GMO appear annually [1-3]. For example, in 2007 began substituting the biotech soybeans of a first-generation (line 40-3-2) on the soybeans of a second-generation (line MON 89788), leading to an immediated increase productivity for the first time [1, 4].

Soybean line MON 89788 was genetically modified with a functional cp4 epsps gene, which encodes for the CP4 EPSPS protein. The FMV/Tsf1 promoter drives constitutive expression of the CP4 EPSPS protein. EPSPS is an enzyme involved in the biosynthesis of aromatic amino acids. Glyphosate inhibits EPSPS, which results in a lack of amino acids essential for growth and development of plants. The majority of EPSPS enzymes are sensitive to glyphosate. The CP4 EPSPS protein, however, is not inhibited by 
glyphosate. MON 89788 expresses the CP4 EPSPS protein and is therefore tolerant to glyphosate. The CP4 EPSPS protein content is about $0.04 \%$ of the total protein in soybean MON $89788[5,6]$.

These genetically modified soybeans of a second- generation have gained access to the food market in the USA, Canada, Taiwan, the Philippines, Japan (2007), Australia, China, Mexico, the European Union (2008), Korea (2009) and Russia [ 2, 5, 7].

The purpose of our work was to investigate the effects of MON 89788 transgenic soybean on the organism of laboratory animals.

Materials and methods of the research. The toxic-hygienic research was carried out in the Department of Toxicology, Safety and Quality of Agricultural Products of the NSC "IECVM" taking into account the basic principles of a bioethics. The in vivo experiment, which was performed on white mice males, lasted 90 days. Before the experiment, the animals were divided into three groups based on analogues ( 20 individuals per each) and maintained for 10 days in an alignment period. Subsequently, the control group of mice received the main diet (MD) - a grain mixture that did not contain soybeans. Mice of the first experimental group received $M D$, in which $30 \%$ of the weight of the grains was replaced with crushed and heat-treated $\left(120^{\circ} \mathrm{C}\right.$, $30 \mathrm{~min}$.) [8] soybeans without genetic modification. The second experimental group received MD, in which $30 \%$ of the weight of the ingredients was replaced with crushed and heat-treated $\left(120^{\circ} \mathrm{C}, 30 \mathrm{~min}\right.$.) soybeans MON 89788. An access to the water was unlimited for all animals throughout the experiment.

During the experiment, clinical observations were performed: appetite, water intake, reaction to external stimuli, behavior, etc. At the 21st, 45th and 90th days from the beginning of the experiment, an euthanasia of mice was carried out through decapitation using a previous deep chloroform anesthesia ( 5 individuals from each group) [9]. Blood samples were taken for further biochemical studies. Pathoanatomical changes were noted.

The content of creatinine and urea; the content of total protein, albumin, $\beta$ - and $\gamma$-globulins concentration, an activity of alanine aminotransferase (AIAT) and aspartate aminotransferase (AsAT) were determined in samples of the blood plasma of mice [10]. The research was conducted using sets of reagents of the Scientific-Research Enterprise "Filisit-Diagnostika" (Ukraine).

Statistical processing of the results was performed using the Student's criterion $(p \leq 0.05)$ [11].

Results of the research. During the experiment, the general state of health of all experimental animals was normal. The mice have eaten well and did not feel thirsty; the coat had a healthy look and shine; the animals were active and did not show aggression or inhibition.

The autopsy showed any macroscopic changes were not in bodies of animals of both experimental groups on the 21st and 45th day. On the 90th day in mice receiving genetically modified soybean, pathological lesions were noted: the liver was flabby, with a clayey colour or much lighter than that of control animals; spleen slightly enlarged, dark-"cherry" color; the small and large intestines are much blown, filled with gas. There was catarrhal inflammation of the mucous membrane of the small intestine in three of five animals in this group.

The biochemical studies results of blood plasma of the white mice are shown in the Table and in Figures 1-4. Available evidence suggests that the impact of both soybeans, as without GM and the line MON 89788 , has been mixed on organism of the white laboratory mice. Thus, on the 21 st day of the experiment, statistically significant reductions of creatinine and urea were observed in organism of animals of both experimental groups relative to control: urea by $16.9 \%$ and $9.7 \%$, and creatinine by $14.4 \%$ and $8.1 \%$, respectively in the first and the second experimental group. On the 45th days after the beginning of the experiment, the indicated values were lower than controls for $38.3 \%$ urea and $24.2 \%$ creatinine in the blood samples of the experimental animals in the first group. In the second group, the tendency to decrease these indicators remained, but there were no statistically significant differences. On the 90th day of the experiment in blood plasma of experimental animals in both groups, the level of urea and creatinine stabilized, and its value approached those in control mice.

The level of activity of aspartate aminotransferase did not differ from the values of this indicator in the control and was stable in blood plasma of experimental animals throughout the experiment. At the same 
time, the level of activity of alanine aminotransferase in blood plasma of mice I and II experimental groups on the 21 st day was higher than control by $35 \%$ and $29.5 \%$, respectively. This trend continued: on the 45th day, this indicator was statistically higher than control in $30.2 \%$ of animals in the first experimental group and $45.8 \%$ in animals of the second experimental group; on the 90th day, the difference was $35.4 \%$ and $47.9 \%$, respectively.

Biochemical studies results of urea, creatinine content, AIAT and AsAT activity in blood plasma of the white mice $(M \pm m ; n=5)$

\begin{tabular}{|c|c|c|c|}
\hline \multirow[b]{2}{*}{ Biochemical indicator } & \multicolumn{3}{|c|}{ Group of animals } \\
\hline & Control & The first group & The second group \\
\hline & \multicolumn{3}{|c|}{ On the 21st day of the experiment } \\
\hline Urea, mmoles/l & $6,99 \pm 0,14$ & $5,81 \pm 0,29^{*}$ & $6,31 \pm 0,14^{*}$ \\
\hline Creatinine, $\mu$ moles/ I & $52,00 \pm 2,00$ & $44,50 \pm 1,17^{*}$ & $47,80 \pm 0,40^{*}$ \\
\hline AIAT, $\mu$ moles/hr× I & $0,88 \pm 0,07$ & $1,19 \pm 0,05^{*}$ & $1,140 \pm 0,003^{*}$ \\
\hline \multirow[t]{2}{*}{ AsAT, $\mu$ moles $/ \mathrm{hr} \times \mathrm{I}$} & $2,10 \pm 0,13$ & $1,97 \pm 0,07$ & $2,11 \pm 0,07$ \\
\hline & \multicolumn{3}{|c|}{ On the 45th day of the experiment } \\
\hline Urea, mmoles/ I & $8,45 \pm 0,86$ & $5,21 \pm 0,29^{*}$ & $7,00 \pm 0,52$ \\
\hline Creatinine, $\mu$ moles/ I & $62,00 \pm 4,12$ & $47,00 \pm 2,32^{*}$ & $58,20 \pm 3,85$ \\
\hline AIAT, $\mu$ moles/hr× I & $0,96 \pm 0,45$ & $1,25 \pm 0,03^{*}$ & $1,400 \pm 0,003^{*}$ \\
\hline \multirow[t]{2}{*}{ AsAT, $\mu$ moles $/ \mathrm{hr} \times \mathrm{I}$} & $2,00 \pm 0,08$ & $2,04 \pm 0,05$ & $2,02 \pm 0,04$ \\
\hline & \multicolumn{3}{|c|}{ On the 90th day of the experiment } \\
\hline Urea, mmoles/ I & $8,00 \pm 0,90$ & $7,41 \pm 0,86$ & $8,25 \pm 0,75$ \\
\hline Creatinine, $\mu$ moles/ I & $60,00 \pm 3,08$ & $57,00 \pm 4,12$ & $59,80 \pm 4,00$ \\
\hline AIAT, $\mu$ moles $/ \mathrm{hr} \times \mathrm{I}$ & $0,96 \pm 0,45$ & $1,30 \pm 0,02^{*}$ & $1,420 \pm 0,005^{*}$ \\
\hline AsAT, $\mu$ moles $/ \mathrm{hr} \times \mathrm{I}$ & $2,00 \pm 0,08$ & $2,04 \pm 0,05$ & $2,02 \pm 0,04$ \\
\hline
\end{tabular}

Note * - the difference between the values of the indicator in the blood of experimental animals relative to the level of the corresponding indicator in the control animals is probably at $p \leq 0.05$

The content of the total protein (Fig. 1) in the blood plasma of the control group mice throughout the experiment was stable and was on average $(55.5 \pm 0.87) \mathrm{g} / \mathrm{I}$. On the $21 \mathrm{st}$ day, there was a tendency to increase this indicator in animals in both experimental groups. On the 90th day, the total protein in blood plasma of mice receiving soybean was statistically higher than control $(p \leq 0.5)$ and was equal to $(60.05 \pm$ $3.25) \mathrm{g} / \mathrm{I}$ and $(59.96 \pm 1.45) \mathrm{g} / \mathrm{I}$ in the first and the second experimental groups, respectively. 


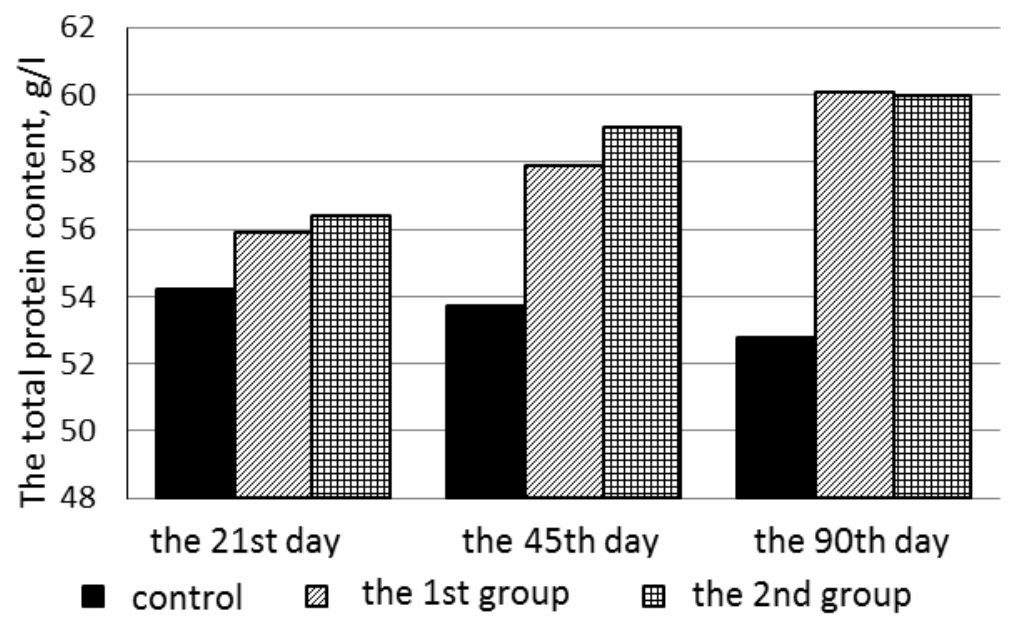

Fig. 1 - Dynamics of the total

protein content in blood plasma of white mice

In this time, the concentration of albumin in blood plasma of control and experimental animals during the experiment varied from $(23,00 \pm 0,15) \mathrm{g} / \mathrm{I}$ to $(26,00 \pm 1,56) \mathrm{g} / \mathrm{I}$ and had no statistically significant changes (Fig. 2 )

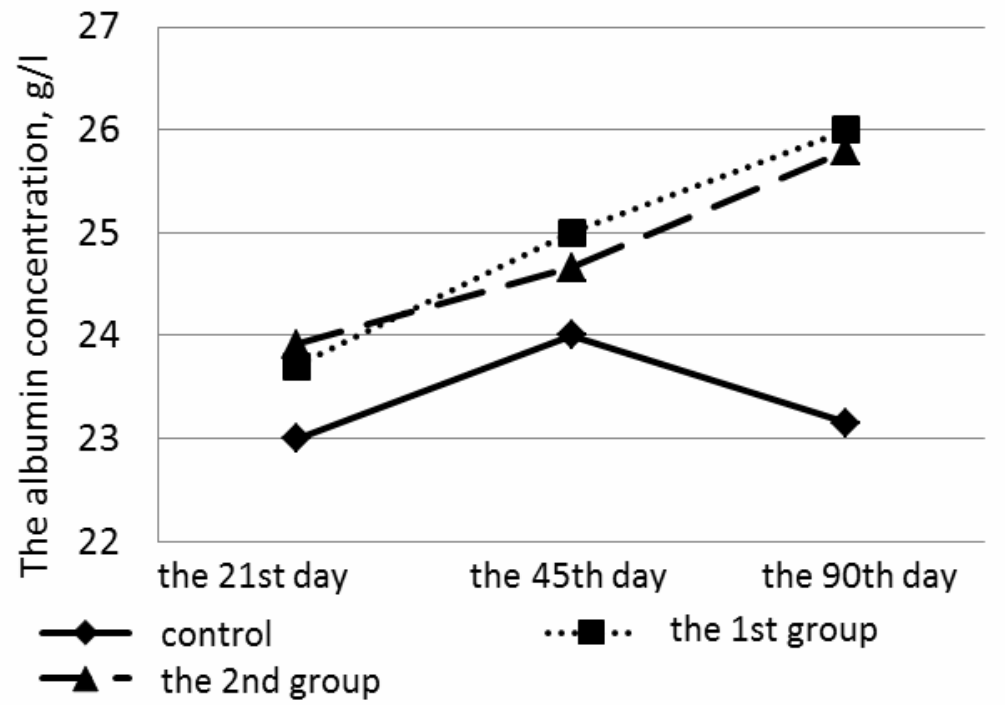

Fig. 2 - Dynamics of the albumin concentration in blood plasma of white mice

The concentration of $\beta$-globulins (Fig. 3) on the 21st day of the experiment was $(11.00 \pm 0.06) \mathrm{g} / \mathrm{I}$ in the control group. In animals of the 2nd experimental group receiving GM-soybean, this indicator was statistically lower $(9.39 \pm 1.08) \mathrm{g} / \mathrm{I}(\mathrm{p} \leq 0.5)$. On the 45th day, the concentration of $\beta$-globulins in blood plasma of control mice and II experimental group equaled - $(10.70 \pm 1.05) \mathrm{g} / \mathrm{I}$ and $(9.58 \pm 0.92) \mathrm{g} / \mathrm{I}$, respectively did not have statistically significant differences.

However, in control animals and experimental groups receiving soybean without GM, this indicator was statistically lower than control and equaled $(8.41 \pm 0.78) \mathrm{g} / \mathrm{I}(\mathrm{p} \leq 0.5)$. On the 90th day, the concentration of $\beta$-globulins in blood plasma of control mice, the 1st, and the 2nd experimental groups did not differ statistically and amounted to $(9.30 \pm 0.95) \mathrm{g} / \mathrm{l},(9.71 \pm 1.82) \mathrm{g} / \mathrm{l}$, and $(10.08 \pm 1.04) \mathrm{g} / \mathrm{l}$, respectively. 


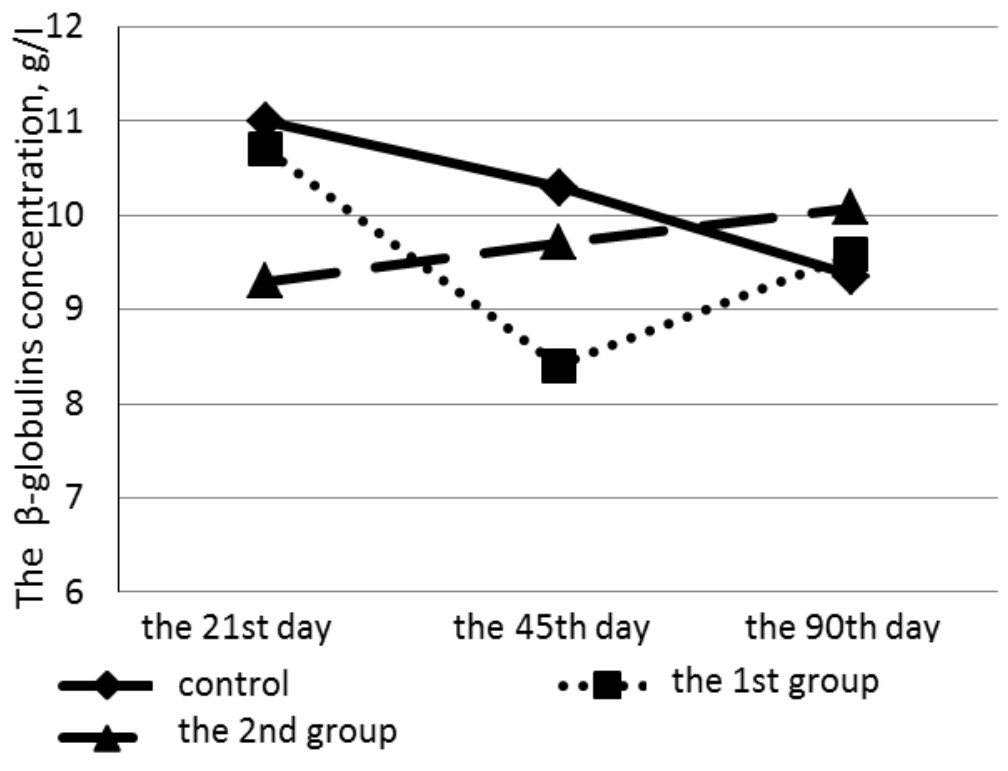

globulins concentration in blood plasma of white mice

Fig. 3 - Dynamics of the $\beta$ -

The concentration of $y$-globulins (Fig. 4) in the blood plasma of control mice was stable throughout the experiment and was equal to $(8.93 \pm 0.33) \mathrm{g} / \mathrm{I}$. In animals of both experimental groups, a statistically significant $(p \leq 0.5)$ increase of this indicator was observed. Thus, in animals of the 1st experimental group on the 21 st day it was $(10,11 \pm 0,08) \mathrm{g} / \mathrm{I}$, on the 45th day - $(12,04 \pm 0,38) \mathrm{g} / \mathrm{I}$,on the 90th day $-(12,34 \pm$ $0.44) \mathrm{g} / \mathrm{l}$; in animals of the 2 nd experimental group - $(11,19 \pm 0,08) ;(13.00 \pm 1.52) ;(12.20 \pm 1.02) \mathrm{g} / \mathrm{l}$, respectively.

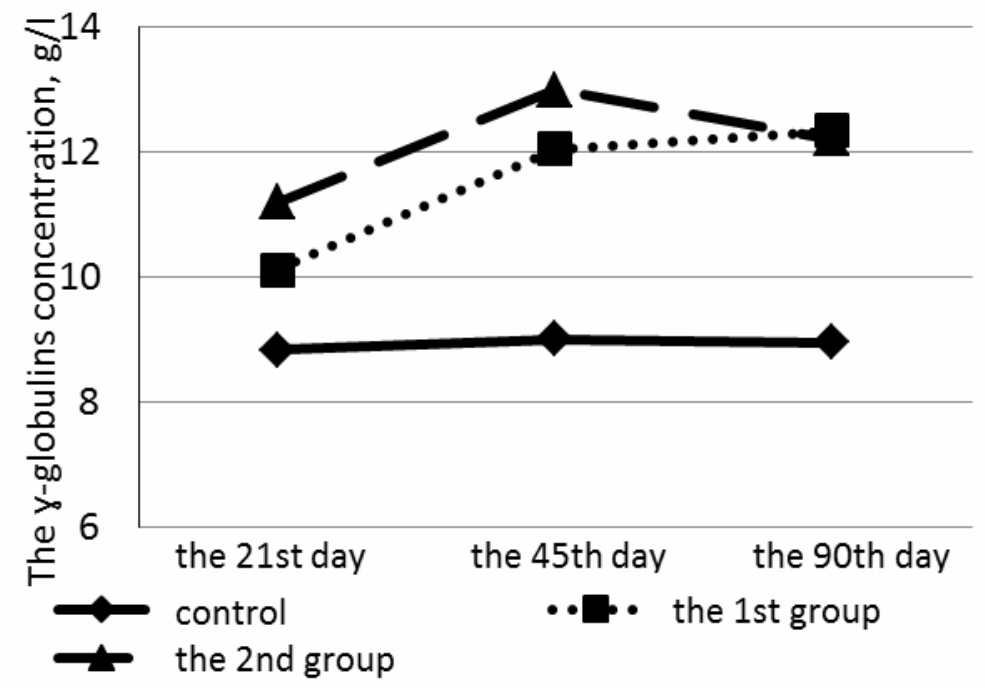

Fig. 4 - Dynamics of the y-globulins concentration in blood plasma of white mice

Thus, an increase in the activity of the alanine transaminase, a statistically significant increase of the level of $\gamma$-globulins in animals of both experimental groups throughout the experiment, a moderate increase in $\beta$ globulin concentration (on the 21st day in the 2nd experimental group and on the 45th day in the 1st experimental group) and a statistically significant increase of the total protein content on the 90th day indicate a violation of the functional state of the liver of mice of both experimental groups. The above may be related to the effect of high levels of protein and fat in the diet of animals in experimental groups compared to the control. At the same time, the dynamics of the increase of AIAT activity, the content of creatinine and urea in plasma of blood of experimental animals and the presence of lesions of liver and bowel on the 90th day in the mice of the 2nd experimental group indicate that a long-term feeding of soybean of line MON 89788 leads to more serious effects in the organism of animals than when feeding soya without GM. Such 
an impact, in our opinion, may be related to the presence of MON 89788 soya beans in the unidentified biologically active compounds formed as a result of the pleiotropic effect of the inbuilt genes and on the possible cumulation of the herbicide gyphosate (roundup) and / or its metabolites [12-14].

\section{Conclusion}

A long-term (about for 3 months and more), unlike a short-term (about 21-45 days), feeding to white mice MON 89788 soybean leads to the lesions: the liver is a light color, flabby consistency; swelling and inflammation of the intestinal mucosa is. According to biochemical markers (a probable increase in the activity of alanine aminotransferase throughout the experiment, an increase in the concentration of $\gamma$ globulins, a moderate growth of $\beta$-globulins on the 21 st day, an increase in the total protein content on the 90th day) it was revealed a violation of the functional state of the liver in the experimental animals.

We consider it expedient to continue the study of transgenic soybean of the second generation MON89788 with the involvement of other types of laboratory animals and poultry for a more profound analysis of its effects on the organism of animals and human.

\section{References}

1. Alekseev Ja.I., Hotjaintceva T.V., Borovskaja S.V., Kolobova O.S., Varlamov D.A., Harchenko P.N. (2011). 35S promoter virusa mozaiki norichnika (P-FMV) - novaja mishen dlya analiza na soderzhanije geneticheski modificirovannyh organizmov. [35S promoter of the mosaic virus of the norichnik (P-FMV) a new target for analysis on the content of genetically modified organisms]. News of the TLC. Vol. 6. P. 156-161. [in Russian].

2. Degrassi G., Alexandrova N., Ripandelli D. (2003). Databases on biotechnology and biosafety of GMOs. Environ. Biosafety Res. Vol. 3. P. 145-160.

3. Robinson K. (Berman V., Tutelian V. Eds.). (2003). Tekhnologija genetichskoj modifikacii I pischevye produkty. [Zdorov'e I bezopasnost potrebiteley. Technology of genetic modification and food products. Health and safety of consumer]. (Transl. A. Reshetov). Brussel. 47 p. [in Russian].

4. Babych A.O., Babych-Poberezhna A.A. (2012). Svitovi ta vitchyzniani tendentsii rozmishchennia vyrobnytstva i vykorystannia soi dlia rozviazannia problemy bilka. [World and domestic trends of production and use of soybeans for solving protein problem]. Kormy i kormovyrobnytstvo. Mizhvidomchyi tematychnyi naukovyi zbirnyk. [Feeds and feeds productions. Interdepartmental Thematic Scientific Collection]. Vinnitsa. Vol. 71. P. 12-26. [in Ukrainian].

5. Opinion of the Scientific Panel on Genetically Modified Organisms on application (reference EFSAGMO-NL-2006-36) for the placing on the market of the glyphosate-tolerant genetically modified soy-bean MON89788, for food and feed uses, import and processing under Regulation (EC) No 1829/2003 from Monsanto. EFSA J. 2008. Vol. 758. P. 1-23.

6. Tyshko N.V., Bricina M.V., Gmoshinskij I.V. et al. (2010). Mediko-biologicheskaja ocenka bezopasnosti genno-inzhenerno-modificirovannoj soi linii MON 89788. Genotoksikologicheskie, immunologicheskie i allergologicheskie issledovanija. [Medico-biological assessment of safety of genetically engineered modified soya line MON 89788. Genotoxicological, immunological and allergological studies]. Voprosy pitanija. [Questions of nutrition]. Vol. 79, № 3. P. 13-17. [in Russian].

7. Svidetel'stvo [Certificate] No. 77.99.26.11.U.100.1.10 of 19.01.2010. Soglasno Reestra produkcii, proshedshej gosudarstvennuju registraciju $v$ Rossijskoj Federacii (vydannye Federal'noj sluzhboj, vkljuchaja Upravlenija) [According to the Register of products that have been registered in the Russian Federation (issued by the Federal Service, including the Office)]. 3 p. [in Russian].

8. Obertyuh Yu.V. (2012). Antypozhyvni rechovyny soi, yikh inaktyvatsiia ta tekhnolohii pererobky soievykh bobiv na promyslovii osnovi y umovakh hospodarstva. [Soybean anti-nutrients, their inactivation and processing technologies for soybeans on an industrial basis and under the conditions of a farm]. Kormy i kormovyrobnytstvo: Vyrobnytstvo ta vykorystannia soi u tvarynnytstvi i ptakhivnytstvi: Mizhvidomchyi tematych. naukovyi zbirnyk. Vinnitsa. Vol. 71. P. 62-71. [in Ukrainian]. 
9. Kotsiumbasa I.la. (Kotsiumbasa I.la Ed.). (2006). Doklinichni doslidzhennia veterynarnykh likarskykh zasobiv. [Pre-clinical studies of veterinary medicines]. Leninhrad. 306 p. [in Ukrainian].

10. Menshikov V.V. (Men'shikov V.V. Ed.). (1987). Laboratornye metody issledovanija $v$ klinike. [Laboratory methods of research in the clinic]. Moskva. 365 p. [in Russian].

11. Lakin G.F. (Lakin G.F. Ed.). (1990). Biometrija: uchebnoe posobie dlja vuzov. [Biometrics: a textbook for high schools]. Moskva: Vysshaja shkola 352 p. [in Russian].

12. Dolaichuk O.P., Fedoruk R.S., Kovalchuk I.I. (2013). Vplyv komponentiv naturalnoi ta henetychno modyfikovanoi soi na pokaznyky imunnoi i reproduktyvnoi system u samyts shchuriv. [Influence of components of natural and genetically modified soya on the indices of immune and reproductive systems in female rats]. Fiziolohichnyi zhurnal: naukovo-teoretychnyi zhurnal. No. 2 (59). P. 65-70. [in Ukrainian].

13. Haidei O.S., Zahrebelnyi V.O., Novazhytska Yu.M. et al. (2015). Analiz rezultativ vyznachennia HMO v syrovyni roslynnoho pokhodzhennia za 2014 rik. [Analysis of the results of GMO determination in plant raw materials in 2014]. Zernovi produkty i kombikormy. No. 1 (57). P. 25-28. [in Ukrainian].

14. Kulyk Ya.M., Rautskiiene V.T., Obertiukh Yu.V. et al. (2015). Vyiavlennia neidentyfikovanoho faktora transhennoi soi u vnutrishnikh orhanakh shchuriv pry yii dovhotryvalomu zghodovuvanni. [Detection of unidentified transgenic soybean factor in the internal organs of rats at its long-term feeding]. Visnyk Vinnytskoho natsionalnoho medychnoho universytetu. No. 2, T. 19. P. 299-302. [in Ukrainian]. 